\title{
Eleventh-Century Drag Acts? Three Old English Poems at Exeter Cathedral
}

\section{Rory G. Critten}

To cite this article: Rory G. Critten (2020) Eleventh-Century Drag Acts? Three Old English Poems at Exeter Cathedral, Exemplaria, 32:4, 346-367, DOI: 10.1080/10412573.2020.1846348

To link to this article: https://doi.org/10.1080/10412573.2020.1846348

册 Published online: 09 Jun 2021.

Submit your article to this journal

Q View related articles $\sqsubset$

View Crossmark data \lceil 


\title{
Eleventh-Century Drag Acts? Three Old English Poems at Exeter Cathedral
}

\author{
Rory G. Critten \\ University of Lausanne
}

\begin{abstract}
The Exeter Book was made towards the end of the tenth century; by the mid-eleventh century at the latest it was at Exeter Cathedral, where bishop Leofric had installed a community of canons living under the Enlarged Rule of Chrodegang. This article seeks to recreate the reception amongst Exeter's mid-eleventh-century canons of three Exeter Book poems: The Wife's Lament, Wulf and Eadwacer, and The Husband's Message. I advance evidence suggesting that The Wife's Lament and Wulf and Eadwacer were performed by Exeter canons and adduce contemporary drag as a parallel to these putative renditions of the poems. My approach affords fresh perspectives on the ambivalent gendering of the texts' voices and the identifications that they might foster between the canons and women beyond the cathedral close. The presentation of The Husband's Message in the Exeter Book suggests that it was destined for private reading. In this mode, I argue, the poem invites its male readers at Exeter Cathedral to perform a mental impersonation of gender by assuming the position of its second person woman addressee. Finally, I show that the three poems support a breadth of thinking about gender that might be matched at other locations in early medieval England.
\end{abstract}

\section{KEYWORDS}

Old English; drag; gender; medieval; The Wife's Lament; Wulf and Eadwacer; The Husband's Message

I take as my point of departure a thought-provoking article by Helene Scheck (2008) that discusses the speakers of The Wife's Lament and Wulf and Eadwacer. Noting a tendency in recent scholarship to view these texts as expressions of women's resistance to male dominance in early medieval culture, Scheck points out that they might equally reflect men's fantasies about women's roles within that world. ${ }^{1}$ The Wife's Lament might be read as a model of revolt in which an abandoned woman harnesses the performative power of words in the form of a curse; or it might be seen to valorize resignation in the face of men's violence. ${ }^{2}$ Wulf and Eadwacer might highlight the harm that feuds between men can do to women, either as lovers or as mothers; or it might perpetuate stereotypes about women's

A draft of this article was read at Kalamazoo in 2019 at a panel organized by Mary Kate Hurley; I am grateful for this opportunity to try out my ideas and would like to thank audience members on that occasion for their helpful feedback, especially Hal Momma, who gave a response to the papers. Thanks also go to friends and colleagues who discussed my argument with me and helped with the bibliography. These include Kevin Curran, Irina Dumitrescu, Elisabeth Dutton, Jenn Thorburn, and Christiania Whitehead. I have benefited from the advice of the reviewers at Exemplaria and of Juliette Vuille and Ricarda Wagner, both of whom read versions of the whole text. Lastly, I thank my students: this paper grows out of an interest in Old English poetry that is the result of several years of undergraduate teaching in Germany and Switzerland. 
propensity towards adultery. ${ }^{3}$ For Scheck, the gender of the poems' anonymous authorship is crucial when it comes to deciding between these readings, and so we reach an impasse. On the one hand, Scheck concludes, "The Wife's Lament and Wulf and Eadwacer are the only extant female-voiced poems written in Old English, and the best candidates, therefore, for female authorship." On the other, "they are also ... the best candidates for maleauthored manipulation of the female subject through literary representation" $(2008,224)$. The tacit assumptions are that women will write in the interests of women and that men will write in the interests of men.

The evidence of early medieval women's authorial activities ranges from Charlemagne forbidding his abbesses to compose vernacular songs to accounts in the Boniface Correspondence and elsewhere of women's authorship of Latin poetry. ${ }^{4}$ More recently, scholars such as Clare A. Lees and Gillian R. Overing (e.g. 2011) have shifted attention towards the ways in which early medieval women might also shape literary culture via their roles as audience members and patrons. Against the backdrop of this information, Scheck's essay usefully intersects with a long history of writing on the anonymous woman's song and affords us a pertinent reminder of men's perennial interest in the production and putting on of textual identities for women. ${ }^{5}$ It is the putting on of identities that interests me here, and, for this reason, I focus not on the authorship of the poems but on their performance. Specifically, I approach The Wife's Lament and Wulf and Eadwacer as texts that were performed by a community of men: the canons of Exeter Cathedral. The manuscript containing the unique extant copies of these poems, the Exeter Book, is thought to have been made towards the end of the tenth century; Exeter Cathedral's canons received it at the latest in 1072, when it was donated to them by the bishop of Exeter, Leofric, upon his death. ${ }^{6}$

I do not wish to suggest that men were the only users of The Wife's Lament and Wulf and Eadwacer ever, either as the poems are presented in the Exeter Book or prior to their compilation in it. Patrick W. Conner $(2005,2008,2011)$ has argued that Old English poems like those in the Exeter Book were read at meetings of parish guilds having both men and women in attendance and I present evidence below of another potentially mixed context in which Old English poetry might have been enjoyed beyond the male cloister. As Christine Fell $(1984,54-55)$ has pointed out, moreover, the existence of Old English words denoting women entertainers suggests that the idea of women's performance of song was not alien to the early medieval English. Still, for my current purposes, I focus on the medieval performance context that can be asserted for the Exeter Book poems with the most confidence: Exeter Cathedral chapter. I want to ask whether feminist interpretations of The Wife's Lament and Wulf and Eadwacer are conceivable in that milieu. What happens when these poems are read and performed by men? Could poems such as these cultivate empathy between genders? A comparison with modern drag theory and practice strikes me as potentially helpful here because theorists and practitioners of drag have often been occupied with a version of the question that I have just asked: when femininity is self-consciously performed, are traditional distinctions between men and women confirmed or eroded?

I start by introducing the theories of drag that inform my approach to the Old English poems. From Judith Butler's productive work on drag I draw an appreciation of the fundamental ambivalence of the form while more recent field studies of drag and transgender subcultures guide my decision to focus on the propensity of drag to foster local community sentiment and always to discover and realize new modes of gender 
identification. From there I go on to describe the potential of dramatic readings of The Wife's Lament and Wulf and Eadwacer at Exeter Cathedral to exploit the indeterminate gendering of their speakers' voices. I am also keen to consider how historical developments at Exeter Cathedral might have shaped these poems' reception at that location. Bishop Leofric's decision to move his see from Crediton to Exeter in 1050 corresponded with a tightening of the restrictions under which the Exeter canons lived. I explore the possibility that the voices of the suffering women who speak The Wife's Lament and Wulf and Eadwacer were adopted by these men in order to express both resistance to Leofric's regime and solidarity with a group of women that was ejected from the cathedral close upon the bishop's installation.

The mode of argumentation that I adopt is often speculative and hypothetical: I seek to elucidate the possible dramatic readings of The Wife's Lament and Wulf and Eadwacer at Exeter Cathedral and the potential receptions that such performances might have met there. Evidence that this way of proceeding is not entirely inappropriate to the context in which I apply it can be drawn from a third Exeter Book poem, The Husband's Message. Where the texts of The Wife's Lament and Wulf and Eadwacer support oral performance, I argue that The Husband's Message invites its male readers at Exeter Cathedral to perform a mental impersonation of gender in the context of a more private reading experience. In order to comprehend this text, its readers must imaginatively construct and inhabit the figure of the second person woman addressee on whom its lines converge. The three Exeter Book poems discussed will thus be shown to make available to Exeter Cathedral's canons a variety of ways of thinking with and about women. I close by suggesting that the poems' reception was not limited to the Exeter milieu and that the attitudes discussed here might be more broadly indicative of attitudes towards gender identity being cultivated throughout early medieval England.

\section{Theories}

In Gender Trouble, Butler famously presents drag as a key to her thesis regarding the performativity of gender: "in imitating gender," Butler writes, "drag implicitly reveals the imitative structure of gender itself - as well as its contingency" ([1990] 2007, 187, emphasis in original). Drag, that is, makes visible the performed - as opposed to innate - nature of gender identity as well as the work that is a precondition of that identity's successful replication and perpetuation. Already in Gender Trouble, however, Butler expressed concern regarding the ambivalence of drag performance, which might either confirm or erode traditional gender categories. If drag is parodic of our everyday gender performance, Butler writes, the effect of its parody will not necessarily be subversive because parodic laughter "depends on a context and reception in which subversive confusions can be fostered." This observation leads directly into a series of questions that continue to resonate in critical discussions of drag:

What performance where will invert the inner/outer distinction and compel a radical rethinking of the psychological presuppositions of gender identity and sexuality? What performance where will compel a reconsideration of the place and stability of the masculine and the feminine? And what kind of gender performance will enact and reveal the performativity of gender itself in a way that destabilizes the naturalized categories of identity and desire? ([1990] 2007, 189, emphasis in original). 
Clearly, not all drag performances will unsettle traditional models of gender. Some more recent ethnographic studies have emphasized that drag might sometimes function as a temporary inversion whose final effect is to reinforce the status quo (e.g. Bridges 2010). Other researchers have emphasized drag's potential to reinforce misogynist power structures and racist stereotypes (e.g. Schacht 2002; Strings and Bui 2014). Nevertheless, Butler's downplaying of the positive agency that might be wielded by performers within her gender system has been virulently critiqued, for example by Marie-Hélène Bourcier (2012). ${ }^{7}$ Focusing on drag in particular, Bourcier (2006) has emphasized the ways in which the form can be productive of subcultural counter-identity, for example in the drag king workshops organized in America in the 1990s by Diane Torr and Annie Sprinkle. Luca Greco (2012), considering Belgian drag king workshops, and Stephan Farrier $(2016,2017)$, considering British drag training and practice, likewise explore the local subcultures that drag supports even at a time when drag is achieving international fame through the mainstream success of RuPaul's Drag Race.

These field-studies have also begun a radical reassessment of the role that trans people play in drag. Butler's elision of the trans experience in her gender theory was addressed by some early respondents to her work, including Jay Prosser (1998) and Viviane K. Namaste (2000). Building on the work of these writers, Bourcier (2006) and Greco (2012) show with particular clarity that drag need not always be understood to mean a man posing as a woman or a woman posing as a man; other combinations of bodies and performances can be envisaged. The relationship between members of drag and trans communities has often been fraught; the fall-out ensuing from RuPaul's assertion in 2018 that trans people should not take part in drag competitions was widely reported (e.g. Levin 2018; McKinnon 2018). But as Bourcier and Greco show, where trans people's contributions to drag are credited, radical redefinitions of the form become possible. Crucial to these researchers' thinking is the notion that a line cannot be drawn between the moment of performance and a world beyond it. Transgender performance can remake the lives of artists and audiences as well as revealing the mechanisms via which normative gender is produced and sustained. ${ }^{8}$

\section{Dramatic reading: performances}

Drag theory reminds us of the essential ambivalence of drag performance, its community-forming function, and its enduring capacity to discover and realize alternatives to binary gender. In what follows, I apply these theoretical insights to an analysis of the performance potential of The Wife's Lament and Wulf and Eadwacer at Exeter Cathedral in the mid-eleventh century. One form that we can imagine these performances taking is dramatic reading. The manner in which the manuscript's scribe presents its texts suggests that some of them were intended for oral rendition. This is the case for Juliana, where, as Katherine O'Brien O'Keeffe (1990, 162-3) notes, manuscript punctuation and enlarged initials often mark the opening of speeches by the saint and her tormentors. Alaric Hall (2002, 12-2) has shown how pointing in the Exeter Book's text of The Wife's Lament likewise clarifies the structure of that poem in a way that would facilitate reading aloud. Wulf and Eadwacer might also have been performed orally. As Ruth P. M. Lehmann (1969) shows, the poem departs from the norms of Old English verse in ways that seem apt to produce a striking acoustic effect. 
While the early medieval English did not have a conception of the theater as a place specially designated for dramatic representation, performance is at the heart of their poetics. The scop is typically presented as an oral performer in Old English poetry, and C. R. Dodwell (2000) has shown the ways in which the performance of verse in early medieval England might redeploy classical theatrical precedent. ${ }^{9}$ At Exeter Cathedral, the culture of prelection, or reading aloud, will have been strong. Kaylin O'Dell (2018) demonstrates the crucial role that dramatic reading played in early medieval English preaching, and Elaine Treharne $(2003,2007,2009)$ and Joyce Hill (2005) have emphasized bishop Leofric's interest in collecting English-language pastoralia. Numerous studies have also emphasized the role that prelection played in medieval education. Marjorie Curry Woods (2019) demonstrates that the memorization and reading out of speeches from the classics, including women's speeches, constituted an important aspect of medieval boys' Latin lessons throughout Europe, and Irina Dumitrescu (2018) offers an insular focus on the pedagogic function of early medieval prelection.

The dramatic readings that I envisage differ from modern drag performance in many important ways relating to the identities of the performers, the materials and technologies available, and the gender politics in whose midst they take place. In particular, the popular approbation that drag now enjoys in some contexts cannot be taken for granted in medieval England, where, as Vern L. Bullough (1996) argues, men's performances of femininity might more often be viewed with suspicion. What is at issue here are the "partial connections," the "queer relations between incommensurate lives and phenomena" that Carolyn Dinshaw explores in her ground-breaking study of Middle English Literature, Getting Medieval $(1999,35)$. The value of the approach resides in the interest of its outcomes. Below, I argue that rethinking The Wife's Lament and Wulf and Eadwacer with drag performance in mind can afford new insight into the familiar topic of these poems' grammatical constitution of their subjects. Scholars who have objected that a man is unlikely to have been able convincingly to perform The Wife's Lament and Wulf and Eadwacer underestimate the capacities of drag artists. ${ }^{10}$ At the same time, it should be pointed out that drag performance affords a potential declaimer of these texts an excellent opportunity to exploit their indeterminate gendering of their speakers' voices.

The gender of the speaker of The Wife's Lament was once hotly debated amongst philologists. In the mid twentieth century, Rudoph C. Bambas (1963) and Martin Stevens (1968) argued on grammatical and other grounds that the poem's "I" must be a man while Angela M. Lucas (1969) and Bruce Mitchell (1972) examining the same evidence concluded that the traditional interpretation of the poem as a woman's monologue was correct. Most readers now follow Mitchell in asserting that the three occurrences of the feminine ending -re in the opening lines of The Wife's Lament establish the gender of the poem's speaker:

Ic pis giedd wrece bi me ful geomorre minre sylfre sið (ll. 1-2a).

[I relate this poem about my very sorry self,/my own journey]. ${ }^{11}$

But aside from this opening sentence, there is little to distinguish The Wife's Lament from the male-voiced elegies. ${ }^{12}$ Like the speaker of The Wanderer, the speaker of The Wife's Lament is an outcast who misses an absent lord and bewails a journey traveled down 
wrocsipas (Wife's Lament, 1. 38; "paths of exile"). In its opening assertion of autobiographical intent and its potentially generalizing close, The Wife's Lament also shares defining formal features with that poem and with The Seafarer.

The indeterminate grammar of the main body of the Wife's Lament facilitates these comparisons. As Stevens (1968, 82-3) points out, any early attempt deliberately to emphasize the speaker's identity as a woman soon peters out. An opportunity to use the clearly feminine adjective ane ("alone") is passed up later in the poem in favor of the deployment of ana, its neutral adverbial equivalent, when the speaker is pictured walking at daybreak in solitude:

ponne ic on uhtan ana gonge

under actreo geond pas eorðscrafu. (11. 35-6)

[when I walk alone at dawn/under the oak tree, through that earthen cave.]

Modern drag performance reminds us that we do not have to accept the binary choice that vexed the twentieth-century philologists. A declaimer of The Wife's Lament at Exeter Cathedral might speak in a voice that is not unequivocally or permanently male or female; it may be both, at different moments in the text, or something else. In light of the similarities between the male-voiced elegies and this poem it seems possible to envisage a performance that would shift from the densely feminized opening of the poem to incorporate a more ambiguously gendered speaker who ponders the fate of geong mon at the text's close:

A scyle geong mon wesan geomormod,

heard heortan gepoht, swylce habban sceal

blipe gebæro, eac pon breostceare,

sinsorgna gedreag, sy æt him sylfum gelong

eal his worulde wyn, sy ful wide fah

feorres folclondes. (11. 42-7)

[May a (the?) young man (person?) always have to be sad-hearted,/the thought of his heart bitter, so he must have/a happy demeanor, and also that heartache,/a host of constant sorrows. On himself let depend/all his worldly joy, let him be exiled far afield/in a far country.]

As my unhappy translation indicates, it is not clear in terms of the grammar: (1) whether the speaker, one of the other figures introduced in the poem, or someone else is implied by the phrase geong mon; (2) whether mon means "man" or "person"; or (3) whether the situation described is definite (i.e. the geong mon) or indefinite (i.e. a geong mon). ${ }^{13}$ The speaker might be claiming that suffering does one good in youth or might be wishing this suffering upon someone who has abandoned them. Critics of Old English poetry have tended to argue that only one of these readings can hold. But if the poem is performed by a man - especially if the man is young - then the rich punning of the text's concluding lines might be demonstrated to an audience with special piquancy.

While the text of The Wife's Lament supports a non-binary performance, a declaimer of Wulf and Eadwacer might want to pivot more obviously between established gender positions. The text is notoriously difficult to translate. On one reading, its opening presents an exile scenario: 
Leodum is minum swylce him mon lac gife;

willað hy hine apecgan, gif he on preat cymeð.

Ungelic is us.

Wulf is on iege, ic on operre.

Fæst is pæt eglond, fenne biworpen.

Sindon wælreowe weras pær on ige;

willað hy hine apecgan, gif he on preat cymeð.

Ungelice is us.

Wulfes ic mines widlastum wenum [d]ogode

ponne hit wæs renig weder ond ic reotugu sæt. (ll. 1-10)

[It is to my people as if they might be given a gift;/they will feed him if he comes into the troop./It is different for us./Wulf is on an island, I on another./That island is secure, surrounded by marsh./There are ferocious men there on the island;/they will feed him, if he comes into the troop./It is different for us./I followed my Wulf's wide tracks expectantly/ when it was rainy weather and I sat weeping.]

One of the poem's many cruces is the verb apecgan: does it mean "to serve (someone) with food" or "to kill (someone)" (cf. DOE s. v. apecgan)? ${ }^{14}$ My translation of the verb (feed) establishes a situation in which a speaker laments a fate shared with someone called Wulf. Both Wulf and the speaker are exiled from their people and their fate is contrasted with that of a man who is also away from home but who would be welcomed on his return, unlike them. Other readings of this scenario are possible, but the important thing to note within the context of this argument is that, until the text's ninth line, there is nothing to identify its speaker either as a man or a woman (some writers even question whether the speaker is human, e.g. Orton 1985). The revelation of the speaker's gender comes in line 10, where the adjectival ending $-u$ on reotog $\underline{u}$ identifies her as a woman. The identification is then repeated in line 14 , where the feminine ending $-e$ is added to the adjective seoc in the phrase "wena me pine/seoce gedydon" (1l. 13-14; "my expectations of you have made me sick").

Comparison with modern drag performance suggests one way in which the revelation in line 10 could be artfully done. In his account of the American Ballroom scene, Marlon M. Bailey describes "realness with a twist," one of the "categories" in which drag performers compete that requires performers to switch gender roles mid act. This is an especially challenging test. "Realness with a twist," Bailey writes, "demonstrates the skill of the competitor to instantly change his/her gender performance from 'unclockable,' meaning they unmark themselves as queer, to 'clockable,' marking themselves as queer" $(2011,379)$. In a parallel study, linguist Rusty Barrett (2017, 33-54) discusses how sudden changes in the pitch of an artist's voice can be used to effect changes of this sort. The artist who performs "realness with a twist" successfully demonstrates that both the normative and non-normative identities so assumed are performed and that the same person might play both parts.

If an audience of Wulf and Eadwacer is allowed to think that the speaker of the first nine lines of the poem is a man, then the text might be made to speak to the nobility of the heroine's suffering, which is revealed in line 10 to be commensurate with that of the familiar figure of the warrior suffering in exile. As we have seen, The Wife's Lament also lends itself to performances that explore women's capacity for dignity in suffering through comparison with the traditional exiled hero. But the scope of these putative 
performances is not easy to circumscribe. A performer of Wulf and Eadwacer could equally aim for bathos. Once the speaker has declared her gender, she goes on to describe what might be a rape:

ponne mec se beaducafa bogum bilegde, wæs me wyn to pon, wæs me hwæpre eac lað. (1l. 11-12)

[when the one bold in battle surrounded me with his hairy arms,/there was joy for me in that, however it was also hateful.]

As Anne L. Klinck $(1987,9)$ points out, Old English bog - from which comes the dative plural form in line 11, bogum - is an odd word choice. Most frequently it refers to the shoulder of an animal where it does not refer to the branch of a tree or bush (now see too DOE s.v. bog [1a, 2a]). My translation of bogum as "in his hairy arms" attempts to capture the mixture of revulsion and fright - and the frisson of excitement - that such a bestial embrace might provoke. It is not difficult to imagine how a moment like this might now be made risible as part of a drag performance: expressions of sexual desire in extremis are stock in trade for the modern performer. Nor is it for nothing that some of the earliest critical writing on drag focused on the form's misogynist potential (e.g. Frye 1983). If the purpose is to send up the heroic model, then this might be achieved at the expense of the image of womanhood.

The famous lines in The Wife's Lament where the speaker regrets meeting her lord might likewise be done with a practiced world-weariness that undercuts the seriousness of the speaker's plight:

ða ic me ful gemæcne monnan funde,

heardsæligne, hygegeomorne,

mod mipendne, morpor hycgendne. (11. 18-20)

[then I found myself a very suitable man,/ill fortuned, sad spirited,/concealing his heart, plotting murder.]

But it is also worth pointing out that skilled drag performers are typically capable of mixing high camp with genuine pathos. This dynamic can often be seen at work in drag celebrity impersonation, in particular in the impersonation of the legends of golden age Hollywood, for example, Bette Davis, Judy Garland, and Marilyn Monroe. ${ }^{15}$ The appeal of these acts seems to reside in their invitation to identify with a troubled woman celebrity who might be both admired and pitied. Their effects might be more or less sympathetic. A drag rendition of Bette Davis in a gay club might serve to revive a misogynist stereotype: the cruel narcissist played by Davis in What Ever Happened to Baby Jane? (1962), for example. Or it might (simultaneously?) promote fellow feeling across time between two disadvantaged, allegedly histrionic, constituencies: women and gay men.

The speakers of The Wife's Lament and Wulf and Eadwacer are also celebrities of sorts. While the date of the poems' first iterations cannot be determined, they set their action in a mythical past. As John D. Niles describes it, their speakers inhabit "a fabulous northern world of lords and retainers, gifts and scops, wars and feuds, dynastic rivalries, arranged marriages, intrigues, and exiled victims of circumstance." They belong not to the late tenthcentury context of the Exeter Book's inscription but to the period of the adventus Saxonum, a time which, Niles continues, "seems to have been the favorite 'once upon a time' of the Anglo-Saxon secular aristocracy" (2003a, 1111-12). In his work on contemporary British 
drag, Stephen Farrier (2016) discusses how the practice of lip-sync performance allows drag artists to connect their audiences with a shared past of continuing protest: so many performers doing Marilyn, Judy, and, more recently, Britney and Cher, through better times and worse. In the next section, I discuss the nature of the protest that the canons of Exeter Cathedral might have pursued through their performances of The Wife's Lament and Wulf and Eadwacer. Performing these heroic women afforded the canons an opportunity to reconnect with their legendary past and to mobilize the traditional image of the suffering woman to serve their own particular purposes in the present. ${ }^{16}$

\section{Dramatic reading: receptions}

On the one hand, Exeter Cathedral chapter looks to have been a propitious location for the performances of The Wife's Lament and Wulf and Eadwacer that I have just described. As Elizabeth M. Tyler (2016) has pointed out, bishop Leofric's interest in secular literature is evidenced not only by his ownership of the Exeter Book but also by his decision to acquire a copy of Statius's Thebaid, manuscripts of which were rare in England before the twelfth century. At the same time, Leofric would seem to have been keen to circumscribe his canons' enjoyment of secular literature in the vernacular. Strictures in the Enlarged Rule of Chrodegang that Leofric prescribed for the canons of Exeter Cathedral indicate that Old English poetry might be viewed with suspicion. Chapter 66 of the Rule forbids attendance at wedding celebrations:

Mæssepreostas and diaconas and subdiaconas and pa pe wifian ne moton, forbugan hi eac oðra manna gyfta, ne ne beon an pam geferscypum pær ma wogerlice leoð and tællice singe, oððe pær lichamana beoð fracodlice gebæru mid saltingum and tumbincgum, pe læs pe se hlyst and seo gesihð wurðe bescyred pæra haligra geryna, and wurðe gefyled mid besmitenysse fracodlicra wurda and wlatuncga. (305)

[Mass-priests and deacons and subdeacons and those who are not allowed to marry shall also avoid the wedding celebrations of other men and take no part in social gatherings where amorous and shameless songs are sung or where lewd gestures of the body are accompanied with singing and dancing, so that their sense of hearing and seeing will not abandon the holy sacraments and fill with the degradation of shameless words and spectacles. (383) $]^{17}$

This mention of songs sung at forbidden gatherings suggests a context of performance where secular poetry in the vernacular might be recited, learned, and shared across an audience presumably comprising both men and women as well as clerics and laypeople. It also gives us a sense of the competition that Leofric faced for his canons' attention. One possibility is that Leofric viewed the Exeter book as a source of dramatic readings that might retain priests who were otherwise apt to stray. Elsewhere the Rule details the arrangements that are to be made for celebrations on feast days at which poetry of the kind preserved in the Exeter Book might have been enjoyed. For example, chapter 34 pictures the canons being entertained in the bishop's own house, or retiring for drinks in a fyrhus, or heated room, in the cathedral complex after a meal in the refectory. The indication that the performance of amorous songs in particular might incur the bishop's displeasure is also useful insofar as it suggests that dramatic readings of The Wife's Lament or Wulf and Eadwacer could constitute an act of resistance to his authority. 
The mid eleventh century saw a tightening in the restrictions under which the canons lived that might have made such resistance feel necessary.

The canons of Exeter Cathedral had received the Enlarged Rule of Chrodegang when Leofric moved his see from Crediton to Exeter in 1050. Leofric may have taken some of his own men with him to Exeter but the foundation there was not created ab initio; it involved the reform of a minster already present in the town. In his history of Exeter Cathedral, Nicholas Orme $(2009,12-17)$ shows that the introduction of the Rule will have meant a reduction in the liberties of the church's clergy from 1050 onwards. Whereas the secular clerics who had staffed the minster before this date were most likely allowed to marry and to live with their wives within the church's precincts, Leofric wanted his clerics to eat and sleep together and hence to be celibate. The detailed strictures in the Rule regarding the nocturnal keeping of the cloister (chapter 10) and the dormitory (chapter 11) suggest that Leofric's plan might meet with some resistance and, as David Blake (1982) has shown, by the twelfth century, conditions seem to have been relaxed.

While the life of Leofric's canons was distinguished from that of contemporary reformed monks by virtue of the canons' greater freedom to work in the world, the descriptions of enclosure in The Wife's Lament and Wulf and Eadwacer thus seem likely to have struck a chord with these men post 1050. Both the Old English poems are replete with images of physical confinement. The speaker of The Wife's Lament complains that she has been compelled to dwell in an inhospitable place, perhaps a derelict pagan sanctuary, where she is bereft of friends (1l. 15-17a). The subterranean location of this dwelling and its isolation are later clarified when it is said to be situated "on wuda bearwe/ under actreo" (1. 27b-28a; "in a grove of trees/under an oak tree"). The dismal properties of this eorðscrœf, or earthen cave, are then developed at some length. Several confining layers are imagined interposing between the speaker and the outside world: encircling woods, dark valleys, tall hills, and thorny briars (1l. 29-32a). There the speaker of the poem walks about alone or sits weeping throughout long summer days (1l. 35-39a). In Wulf and Eadwacer, these descriptions of isolation are literalized: "Wulf is on iege, ic on operre" (1. 4; "Wulf is on an island, I on another").

Medievalists have picked up on the imagery of confinement in The Wife's Lament and Wulf and Eadwacer and suggested that it reflects a concern with the increasingly narrow enclosure of women religious leading up to the late tenth-century Benedictine Reform. In her study of the early medieval discourse of female enclosure, Shari Horner (2001, 29-63) shows how the ideal of the confined woman that is inscribed in reformed monastic rules, episcopal letters, and convent architecture also shapes vernacular literary productions such as the poems that I have been discussing. Horner highlights resonances in these texts' vocabulary that are suggestive of the monastic world. The line "Đa ic me feran gewat folgað secan" (The Wife's Lament, 1. 9), while usually translated "then I went traveling to seek a retinue," might also refer to taking holy orders, for example, and the compound "actreo" (The Wife's Lament, 1. 28, 1. 36), literally "oak tree," might be taken to denote the cross. On this reading, The Wife's Lament and Wulf and Eadwacer are approximated to the planctus monialis, a type of poem giving the lament of an unhappily or unwillingly confessed nun who chafes against the restrictive confines of her cloister.

William of Malmesbury, who visited Exeter in the 1120s, offers a tantalizing glimpse of a situation in which the path of Exeter's cathedral canons might have crossed that of 
Horner's nuns. Leofric established his bishopric at Exeter, William asserts, "eiectis sanctimonialibus a sancti Petri monasterio" (I: 314-15; "having sent the nuns packing from the monastery of St Peter"). ${ }^{18}$ William is the only authority for the claim that St Peter's Exeter, which Leofric took over as his cathedral, ever housed nuns; in her survey of nunneries in early medieval England Sarah Foot $(2000,85-8)$ views the chronicler's assertion skeptically. The notion that the newly reformed church was founded at women's expense is worth retaining, however. Orme suggests that William's report reflects "a muddled memory of [Leofric] removing women from the minster area who were living there as the wives of clerks" $(2009,12)$. Elsewhere Orme $(2013,44)$ notes that the first nunnery in Devon was probably founded at Polsloe in about 1160. Perhaps, then, the women that The Wife's Lament and Wulf and Eadwacer might most readily call to mind in mid eleventh-century Exeter were not reformed nuns but the eleventh-century canons' exiled wives, whose departure from the cathedral close would enter local legend in the form of the story that William of Malmesbury picked up in the 1120s.

The Wife's Lament and Wulf and Eadwacer offered performers and audiences at Exeter Cathedral two rich examples of women's suffering on which they might draw to express their own disquiet under Leofric's new regime. The poems' depictions of the unhappy Germanic heroine were apt to support identification both with the figure of the confined nun, who might have been a rather abstract presence in eleventh-century Exeter, and with the canons' wives, who were separated from their husbands upon Leofric's arrival at Exeter; many of these women will presumably have taken lodgings in the town around the cathedral. But what kind of identification is this? Would the idea of the suffering, enclosed or exiled woman have been evoked solely to serve the purposes of the canons' own self-expression and resistance to episcopal authority? Or might the identifications promoted by the texts have extended to sympathy with real women in circumstances similar to their speakers'?

Analyses of men's uses of women's voices in other early contexts suggest the often selfserving nature of men's drag performance. ${ }^{19}$ These subtle - and damning - accounts of men's uses of women's voices in order to advance their own political, social, and pedagogic aims stand as a powerful warning against the overoptimistic interpretation of dramatic readings of The Wife's Lament and Wulf and Eadwacer at Exeter Cathedral. Above, I emphasized the essential ambivalence of drag and pointed out where dramatic readings of The Wife's Lament and Wulf and Eadwacer might tip into misogyny. Now it seems important to explore the counter-argument. When we consider the particular situation of the poems' reception in mid-eleventh-century Exeter, it becomes at least possible to imagine how solidarity between men and women outside the cloister might have been fostered through the canons' dramatic reading of these texts. The fluid gendering of voice in the Old English poems might encourage male declaimers of the poems and their audiences to imagine themselves in the place of their women speakers, and the recent history of Exeter Cathedral will have ensured that real women's suffering through separation and exile was more than a theoretical principle in their midst. Many of Exeter Cathedral's canons will have known such suffering women firsthand; some of them may have been their husbands. Dramatic readings of The Wife's Lament and Wulf and Eadwacer need not have resulted in the erasure of these women's experiences. The Old English poems could also prompt new thinking about the elements that united the newly regulated Exeter Cathedral canons with their women neighbors beyond the cloister walls. 


\section{Private reading: The Husband's Message}

The previous sections argue that Exeter Cathedral's canons could reimagine their own situation through comparison with the suffering heroines of The Wife's Lament and Wulf and Eadwacer and that they might possess the emotional intelligence to pursue the implications of this identification beyond the moment of a putative dramatic reading of these works. Crucial to my claim has been the notion that The Wife's Lament and Wulf and Eadwacer were apt to have been performed by the canons and that their representation in this manner might persuasively illustrate the overlap explored in both texts between men's and women's identities and experiences.

I now turn to another poem in the canons' book that seems more likely to have been read privately at Exeter. In contrast to the open mode of address espoused in The Wife's Lament and Wulf and Eadwacer, The Husband's Message speaks to its readers individually and in an atmosphere of secrecy: "Nu ic onsundran pe secgan wille" (1. 1; "now I will say to you apart"). The runic passage with which the poem closes also suggests that the text was designed to be seen rather than heard because the various possible meanings that the runes bear cannot easily be represented in oral performance; a declaimer of the poem must decide, for example, whether the symbols are to be realized as words or letters. If The Husband's Message ever were read out from the Exeter Book, the text must have been carefully studied beforehand. The unity of the poem is not immediately clear in the manuscript, where it is copied out, apparently accidentally, as if it were three independent works, corresponding to ll. 1-12, 13-25, and 26-54 of the edited text. ${ }^{20}$ A canon performing the poem at Exeter Cathedral would first have to piece it together in his mind.

What I want to suggest is that the more intimate situation of reception in which the Exeter Book's text of The Husband's Message asks to be considered makes available to the cathedral's canons another lesson on the possibility of empathy between genders. At issue here is the thinking that might be expected from these men. If the foregoing argument has proceeded speculatively and hypothetically, particularly as regards the identifications that performances of The Wife's Lament and Wulf and Eadwacer could foster, then the inclusion of The Husband's Message in the Exeter Book suggests that the canons might think experimentally too. In order to understand this riddling text, a potential reader must manifest the talent for inter-gendered thought that is described above. The private and public reading experiences that I describe can thus be seen as mutually complimentary parts of a general readiness amongst the readers represented by the Exeter Book to think through alternative gender positions.

The story of The Husband's Message is straightforward enough: an exiled lord sends a message to a woman telling her that she should travel across the sea to the land where he now resides so that they can be together again. As was the case in Wulf and Eadwacer, however, the gender of the poem's woman character is not immediately transparent, and the way in which the lord's message is transmitted to her only gradually becomes clear. In its now partly charred state, ${ }^{21}$ we must wait until line $8 b$ of the text to learn that its speaker is a messenger who has arrived to tell us how we must think about the love of a lord whom we share:

eom nu her cumen

on ceolpele, ond nu cunnan scealt

hu pu ymb modlufun mines frean 
on hyge hycge. Ic gehatan dear

pæt pu pær tirfæste treowe findest. (ll. 8b-12)

[I have come here now/on a ship plank, and now you shall know/how you should about my lord's heart-love/think in your mind. I dare to vow/that you will find glorious faith there.]

The messenger asks us to look into our mind but is in no doubt about what we must find there: glorious treowe. The semantic implications of treowe are broader than my Modern English translation (faith) can suggest, encompassing the keeping of promises and observing fealty (cf. Bosworth-Toller s.v. treow). The implication is that to think otherwise than the messenger would be to be guilty of ignominious disloyalty.

Matching this first portion of the poem as it is presented in the Exeter Book (ll. 1-12) to the manuscript section that follows (1l. 13-25) involves the recognition that the messenger is determined both to call us to account and to compel us to assume a particular viewpoint. In lines directly following those cited above, we are reminded of promises that we made to the lord in happier times:

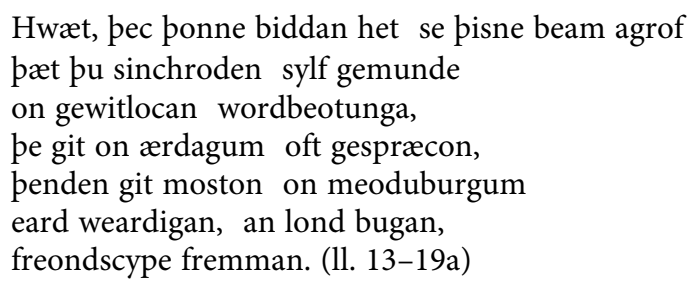

[Listen! Then he who carved this beam commanded you/that you yourself, adorned with treasure, should remember/in your mind the promises in words/that you two often spoke in former days,/while in towns where mead is drunk you both might/keep the land, inhabit one and the same land,/craft friendship.]

Like The Wife's Lament and Wulf and Eadwacer, here The Husband's Message deploys language that might refer either to a love relationship or to the feudal bond linking a warrior to his lord. The word sinchroden (1. 14; "adorned with treasure") is used to describe the luxury that the addressee enjoyed prior to the lord's exile but this adjective is uninflected and there is nothing inherently feminine about the designation. When Wiglaf tries to instill a sense of loyalty in Beowulf's men before the king's final battle with the dragon, he likewise emphasizes the value of the gifts that the soldiers had previously received from their commander (11. 2631-60). ${ }^{22}$ Nor is there anything necessarily amorous about the freondscype (1. 19; "friendship") that the addressee and the lord are said to have crafted together. This word has traditionally been glossed and translated as "friendship" or "love" as if the two words were interchangeable (cf. Klinck 1992, 404; Leslie 1961, 79). Thus in his translation, Kevin Crossley-Holland invites readers to imagine the characters in the poem living "in the same land in love together" at lines 18-19 ([1982] $1999,58)$. But the only time that the DOE suggests that freondscype might mean "love" is where the term has been used to gloss the Latin word dilectio, which in that instance refers to the love of God for mankind (see DOE s. v. freondscipe [1.b.ii.c.]). ${ }^{23}$

Only in the poem's third manuscript section (ll. 26-54), at line 48, is it finally made clear that the poem addresses a peodnes dohtor, or ruler's daughter: 
Nu se mon hafað

wean oferwunnen; nis him wilna gadne meara ne maðma ne meododreama, ænges ofer eorpan eorlgestreona, peodnes dohtor, gif he pin beheah. (ll. 44b-48)

[Now the man has/overcome misfortunes; he lacks no pleasures,/nor horses, nor treasures, nor joys of mead,/nor any of the earthly treasures of noblemen,/O ruler's daughter, if he possesses you.]

Directly after this passage, the nature of the lord's message also becomes clear. Prior to this moment, the messenger had alluded obliquely to the lord as the man "se pisne beam agrof" (1. 13; "who carved this beam"). In the poem's closing runic passage, we discover what was actually written on the piece of wood (I show the runes; Muir transliterates them):

Ofer eald gebeot incer twega,

gehyre ic ætsomne .4.R. geador

.T.P. ond .X. ape benemnan,

pæt he pa wære ond pa winetreowe

be him lifgendum læstan wolde,

pe git on ærdagum oft gespræconn. (1l. 49-54)

[Concerning the long-established vow between you two,/I hear conjoined ५. R. together/.T.P. and .X. declare by oath,/that he the agreement and the pledge of friendship/would (i.e. intends to) uphold, while he lives,/that the two of you often spoke in former days.]

Here we understand that the message sent to the peodnes dohtor is a piece of wood on which these symbols have been inscribed - perhaps the mast of a ship sent to take her to the lord - and that the poem we have just read is her extrapolation of their meaning in an imaginative act whereby she envisages the piece of wood speaking to her. ${ }^{24}$

At this moment in the poem, a first-time reader is induced to understand that the manipulative tones of the messenger-figure alluded to above are internally generated by the addressee. The poem's closing lines again show her anticipating her lord's arguments. She imagines him both insisting on their union through the use of the dual pronoun (incer, reinforced by twega in 1. 49; and git in 1. 54) and emphasizing the solemnity of their alleged vow by repeatedly naming it (it is called a gebeot in 1. 49 and, more definitely, $p a$ wore and $p a$ winetreowe in 1. 52). The ambivalence of the modal verb wolde in line 53 is especially revealing of her psychology. If it is interpreted as a subjunctive, then line 53 might be read as a repetition of the lord's promise to keep his pledge, as per my translation. If it is construed as an indicative, however, a Modern English translation suggests smoldering resentment: "[the vows that he] wanted to uphold (but was prevented from upholding by your inconstancy)." The flexibility of Old English here makes perceptible a mode of interaction in which passive forms of aggression are anticipated mingling with clearer expressions of entitlement. ${ }^{25}$

For a male reader of the poem - for example, one of the canons at Exeter Cathedral the conclusion of The Husband's Message is doubly surprising. If he gets this far in the text's argument, he must recognize not only the complexity of the woman addressee's reaction to her lord's claim upon her but also that he has been thinking like her all along. Readers of 
The Husband's Message who reach its close can only discover the thoughts of the peodnes dohtor because they have already been theirs. Reaching this epiphany is not easy work; the poem demands the same careful approach as the riddles that accompany it in the Exeter Book. In a final twist, the concluding runic passage encourages us to recognize the difficulty of ever knowing another's mind perfectly. Can we be sure that thinking like the addressee will mean that we interpret the runes in precisely the same way as her? To what extent is the poem that we have constructed a product of our own imaginative biases? Does the story that we have arrived at illuminate or overwrite the addressee's predicament? In posing these questions, the conclusion to The Husband's Message thematizes several of the issues raised by the theorists of drag performance whose work I considered above.

It might be argued that the manuscript presentation of The Husband's Message forecloses interpretations of the poem as a unified text in the fashion that I have described; certainly, its mise en page has been interpreted otherwise (e.g. Kaske 1967; Goldsmith 1975). But divisions between items are also unclear elsewhere in the Exeter Book, and it seems probable that, like their modern counterparts, medieval readers will actively have reinterpreted the manuscript's disposition of its materials. ${ }^{26}$ For some readers at Exeter, The Husband's Message might finally have coalesced around an antifeminist stereotype: the fearful, potentially unfaithful woman, who is to be won by the mention of riches. But anyone at Exeter Cathedral who mentally engaged in putting this poem together embarked upon a timeconsuming process whose success relied on an ability to conceive multiple outcomes for the work. The effort of attention required to see the poem in the Exeter Book seems likely to have fostered a probing interaction with an actively conceived psychology whose complex experience recalls the potential vicissitudes of the lord-retainer relationship.

\section{Conclusion}

This article has used the example of drag performance to argue that dramatic readings of The Wife's Lament and Wulf and Eadwacer by the canons at Exeter Cathedral could foster understanding and solidarity between the canons and the women living beyond the cathedral close. While the potential of drag performance is always multiple and the possibility that drag might erase or devalue women's experiences must always be considered, I have developed my more optimistic reading in light of recent work on the community-forming functions of drag and via analyses of the historical situation of Exeter Cathedral's canons and of one other Exeter Book poem, The Husband's Message. My interpretation of that last text suggests that the users of this manuscript might experiment with the adoption of women's perspectives beyond the sphere of a particular performance in individual acts of private reading. In this instance we can see playing out with special clarity the claims of modern theorists of drag that performance can shape mentalities and that in any drag act the lines between performance and reception will be blurred.

Where I have attempted to recreate the reception of The Wife's Lament, Wulf and Eadwacer, and The Husband's Message at Exeter Cathedral, I have contributed to a trend in Old English scholarship that considers the potential uses of early English literature in the manuscripts that preserve it, most of which date to the end of the Old English period. ${ }^{27}$ But studies of the provenance of the Exeter Book and its texts suggest that the reach of the poems that I have discussed extended beyond the Exeter milieu. Work by Klinck (1992, 
13-21) on the language of some of the Exeter Book's texts suggests that they originated in different parts of England at different times, and work by Muir (2000, I: 16-25) on the compilation of the manuscript holds open the possibility of its copying from a similar or identical codex that is now lost. The Exeter Book itself might have been inscribed at Crediton or Exeter, as Conner (1993, 48-94) has argued; or it might have been made at Canterbury, or Glastonbury, before bishop Leofric acquired it, as Richard Gameson (1996) and Robert M. Butler (2004) have suggested. Work on other Old English text types, especially hagiography, likewise suggests the more general availability of vernacular works exploring the different gendering of women (e.g. Norris 2013; Vuille forthcoming; Watt and Lees, 2011). In closing, it bears emphasizing that the exploration of gender difference in the Exeter Book's copies of The Wife's Lament, Wulf and Eadwacer, and The Husband's Message may account for a larger part of the experience of vernacular literature in early medieval England than we are currently able to recover.

\section{Notes}

1. In addition to the studies by Belanoff $(1990,2002)$, Bennett (1994), and Desmond (1990) that Scheck mentions, see Klein (2006).

2. On these divergent readings, see Niles (2003a). On cursing in the poem, see too Straus (1981).

3. For an account of some influential interpretations of Wulf and Eadwacer, see Aertsen (1994).

4. For a useful summary, see Robinson (1990). On women's authorship of Anglo-Latin poetry, see too Stevenson (2005).

5. On the anonymous woman's song in medieval scholarship, see Plummer (1981). On the form more generally, see Klinck (e.g. 2012). Schibanoff (1982) anticipates some of Scheck's conclusions.

6. For a convenient biography of Leofric, see Barlow (1972). The provenance of the Exeter Book is discussed below.

7. Returning to the topic of drag in Bodies that Matter ([1993] 2011, 84-95) and in the new Preface for Gender Trouble ([1999] 2007, xxii-xxv), Butler moved further away from the idea that drag might have a destabilizing function. By the time Butler reaches Undoing Gender (2004), drag's potential has been reduced to a capacity to thematize - but not disrupt - traditional gender models. There Butler asserts that drag might clarify our understanding of gender according to an ontology - "an account of what gender is" but drag's potential is limited to its capacity to suggest that this ontology might be "open to rearticulation" (2004, 214, emphasis in original).

8. On the implication of trans performers in drag and for a useful synthesis of recent drag theory, see further Stokoe (2019).

9. Juliette Vuille reminds me that, like the Exeter Book, the monastic origins of medieval drama can be traced back to the late tenth century, which sees the inscription at Winchester of the oldest extant church play, the Visitatio sepulchri (see Ogden 2002, 19-34).

10. See, for example, Bishop (2005, 24-5). The best introduction to drag is to experience it live. A variety of printed studies is available. These run from synchronic ethnographies (e.g. Newton [1972] 1979; Rupp and Taylor 2003) to popular histories (e.g. Baker 1994) and glossaries (e.g. De Zanet and Garcia forthcoming). For an ambitious world history, see Senelick (2000).

11. Citations of the Exeter Book poems discussed in this paper are given by line from the edition by Muir (2000). The translations, my own throughout, draw on glosses and explanatory material in Klinck (1992) and Leslie (1961). For close yet readable translations of The Wife's Lament and Wulf and Eadwacer, see Liuzza (2014). Briefly, the grammatical argument against the identification of the speaker of lines 1-2a of The Wife's Lament as a woman, most extensively developed by Stevens (1968), claimed that: (1) the -re ending on geomorre is adverbial, not adjectival (the translation would thus run: "I relate this poem about me very 
sorrowfully"); and (2) that the feminine endings in the phrase minre sylfre do not reflect the gender of the speaker but are in agreement with an otherwise unattested feminine dative form of the noun sið (1. 2; "journey"). Mitchell (1972) accepts the first of these two arguments but finds the second improbable.

12. So Rissanen (1969). On the critical history of discussions of this point, see Clark (2009, 22-36).

13. Some of the complexities of this phrase are discussed in Niles (2003a, 1113).

14. For analysis of some of the grammatical and lexical difficulties posed by Wulf and Eadwacer, including apecgan, see Baker (1981).

15. For discussion, see Senelick (2000, 385-89). For classic examples, google Jim Bailey, Charles Busch, Jimmy James, Charles Pierce, and Craig Russell.

16. Here the argument connects with my previous work (Critten 2019) on "medieval medievalism," a term that I use to highlight the nostalgic elaboration of identities subsequently defined as medieval - here, the Germanic heroine - already during the Middle Ages. On the figure of the lamenting woman in Germanic tradition, see Renoir (1975).

17. The Old English version of the Enlarged Rule of Chrodegang and its modern English translation are cited by page number from Langefeld (2003). Langefeld edits the bilingual (Latin-English) version of the Enlarged Rule that was written at Exeter in Leofric's scriptorium.

18. Cited by volume and page number from the edition and translation by Winterbottom (2007).

19. For example, in her study of early modern literature, Harvey (1992) argues that Spencer, Erasmus, and Donne each impersonate women in order to serve their own projects and, in so doing, perpetuate stereotypes that limit real women's options; Sponsler (1997) contends that late medieval laboring men challenged their superiors in drag without improving gender relations in the process; and, with reference to early medieval England, Patricia Clare Ingham (2003) shows how, throughout Old English literature, the promulgation of images of keening women facilitated a social and cultural shift whereby homosocial bonds between men were strengthened at the expense of family ties including men and women. Commenting on the closest historical parallel for the kinds of performance that I have discussed - the classroom rendition of the speeches of suffering classical heroines Marjorie Curry Woods (2019, 33-35) is likewise skeptical of the notion that rehearsing women's pain might foster empathic responses. Drawing on research in neuroscience and on the modern novel, Woods asserts that the perception of fictionality might enhance the emotional appeal of classical women's suffering speeches precisely because it relieves performers and audiences of any obligation to act differently in the real world.

20. The three manuscript subsections of The Husband's Message begin with initials of the size marking the openings of the poems that precede and follow it (Riddle 60 and The Ruin); the last lines of the poem's first two subsections are right justified, a layout used elsewhere in the book to signal the end of texts; and all three of the subsections of the poem are concluded with the manuscript punctuation mark normally used to signal a close (Muir 2006, 191). Facsimile images of the poems discussed in this article can be seen on the DVD that accompanies Muir's edition of the Exeter Book; The Husband's Message is copied on fol. $123 r$-v. Alternatively, see the plates in Klinck (1992).

21. On the damage suffered by the Exeter Book, see Muir (2000, 13-15).

22. Cited by line from the edition by Fulk, Bjork and Niles (2008).

23. At work here would seem to be the silent heterosexism of medieval editors, scholars, and translators, discussed by Clark $(2009,22-36)$. The only clue that we are given as to the addressee's gender prior to line 48 is the messenger's report of the lord's hope that he and the addressee might once more distribute treasure and nailed rings to the lord's men and companions (1l. 34-35a): this might be thought to be an activity suitable for a lord and his lady to do together. But this reading relies on a conjectural completion of the manuscript's damaged text: "secgum ond gesipum s[inc brytnian]/næglede beagas" where "s[inc brytnian]" translates "distribute treasure." 
24. This is the interpretation of the poem developed by Niles (2003b), who also discusses of the runes' potential meanings. Peter Orton $(1981,51)$ has suggestively compared the addressee's process of interpretation to that by which a person might now read between the lines of a brief letter or postcard received from an old friend or lover.

25. On the apparently coercive relationship between the addressee of The Husband's Message and her lord, see further Edlich-Muth (2014).

26. Debates among editors regarding the Exeter Book's textual boundaries are discussed by Muir (2000, I: 16-25). See too Weiskott (2019).

27. This trend can be traced at least as far back as Robinson (1980).

\section{Notes on contributor}

Rory G. Critten teaches Old and Middle English at the University of Lausanne, Switzerland. He is the author of Author, Scribe, and Book in Late Medieval English Literature (D. S. Brewer, 2018) and, with Glenn D. Burger, co-editor of Household Knowledges in Late-Medieval England and France (Manchester University Press, 2019). His work on Old English poetry has also appeared in the Journal of Medieval and Early Modern Studies.

\section{References}

Aertsen, Henk. 1994. “Wulf and Eadwacer: A Woman's Cri de Coeur-For Whom? For What?” In Companion to Old English Poetry, edited by Henk Aertsen and Rolf H. Bremmer, 119-144. Amsterdam: VU University Press.

Bailey, Marlon M. 2011. "Gender/Racial Realness: Theorizing the Gender System in Ballroom Culture." Feminist Studies 37 (2): 365-386.

Baker, Peter S. 1981. "The Ambiguity of Wulf and Eadwacer." Studies in Philology 78 (5): 39-51.

Baker, Roger. 1994. Drag: A History of Female Impersonation in the Performing Arts. New York: New York University Press.

Bambas, Rudolph C. 1963. "Another View of the Old English Wife's Lament." The Journal of English and Germanic Philology 62 (2): 303-309.

Barlow, Frank. 1972. "Leofric and his Times." In Leofric of Exeter: Essays in Commemoration of the Foundation of Exeter Cathedral Library in A.D. 1072, by Frank Barlow, Kathleen M. Dexter, Audrey M. Erskine, and L. J. Lloyd, 1-16. Exeter: University of Exeter Press.

Barrett, Rusty. 2017. From Drag Queens to Leathermen: Language, Gender, and Gay Male Subcultures. Oxford: Oxford University Press.

Belanoff, Pat. 2002. "Ides ... geomrode giddum: The Old English Female Lament." In Medieval Woman's Song: Cross-Cultural Approaches, edited by Anne L. Klinck and Ann Marie Rasmussen, 29-46. Philadelphia: University of Pennsylvania Press.

Belanoff, Patricia A. 1990. “Women's Songs, Women's Language: Wulf and Eadwacer and The Wife's Lament." In New Readings on Women in Old English Literature, edited by Helen Damico and Alexandra Hennessey Olsen, 193-203. Bloomington: Indiana University Press.

Bennett, Helen T. 1994. "Exile and the Semiosis of Gender in Old English Elegies." In Class and Gender in Early English Literature: Intersections, edited by Britton J. Harwood and Gillian R. Overing, 43-58. Bloomington: Indiana University Press.

Bishop, Chris. 2005. "The Erotic Poetry of the Exeter Book." Journal of the Australian Early Medieval Association 1: 7-26.

Blake, David. 1982. "The Development of the Chapter of the Diocese of Exeter, 1050-1161." Journal of Medieval History 8 (1): 1-11.

Bosworth, Joseph. An Anglo-Saxon Dictionary Online. http://www.bosworthtoller.com/ .

Bourcier, Marie-Hélène. 2012. " $F^{* * *}$ the Politics of Disempowerment in the Second Butler." Paragraph 35 (2): 233-253. 
Bourcier, Marie-Hélène, ed. 2006. “Des 'femmes travesties' aux pratiques transgenres: repenser et queeriser le travestissement.” In Queer Zones: Politique des identités sexuelles et des savoirs. 2nd ed., 113-127. Paris: Amsterdam.

Bridges, Tristan S. 2010. "Men Just Weren't Made to Do This: Performances of Drag at 'Walk a Mile in Her Shoes' Marches." Gender \& Society 24 (1): 5-30.

Bullough, Vern L. 1996. "Cross Dressing and Gender Role Change in the Middle Ages." In Handbook of Medieval Sexuality, edited by Vern L. Bullough and James A. Brundage, 223-242. New York: Garland.

Butler, Judith. [1990] 2007. Gender Trouble: Feminism and the Subversion of Identity [includes 1999 Preface]. London: Routledge.

Butler, Judith. [1993] 2011. Bodies that Matter: On the Discursive Limits of "Sex. " London: Routledge.

Butler, Judith. 2004. Undoing Gender. London: Routledge.

Butler, Robert M. 2004. "Glastonbury and the Early History of the Exeter Book." In Old English Literature in its Manuscript Context, edited by Joyce Tally Lionarons, 173-215. Morgantown: West Virginia University Press.

Clark, David. 2009. Between Medieval Men: Male Friendship and Desire in Early Medieval English Literature. Oxford: Oxford University Press.

Conner, Patrick W. 1993. Anglo-Saxon Exeter: A Tenth-Century Cultural History. Woodbridge: The Boydell Press.

Conner, Patrick W. 2005. “The Old English Elegy: A Historicization.” In Readings in Medieval Texts: Interpreting Old and Middle English Literature, edited by David F. Johnson and Elaine Treharne, 30-45. Oxford: Oxford University Press.

Conner, Patrick W. 2008. "Parish Guilds and the Production of Old English Literature in the Public Sphere." In Intertexts: Studies in Anglo-Saxon Culture Presented to Paul E. Szarmach, edited by Virginia Blanton and Helene Scheck, 255-271. Turnhout: Brepols.

Conner, Patrick W. 2011. "Four Contiguous Poems in the Exeter Book: A Combined Reading of Homiletic Fragment III, Soul and Body II, Deor, and Wulf and Eadwacer." In The Genesis of Books: Studies in the Scribal Culture of Medieval England in Honour of A. N. Doane, edited by Matthew T. Hussey and John D. Niles, 117-136. Turnhout: Brepols.

Critten, Rory G. 2019. "Via Rome: Medieval Medievalisms in the Old English Ruin." Journal of Medieval and Early Modern Studies 49 (2): 209-231.

Crossley-Holland, Kevin. [1982] 1999. The Anglo-Saxon World: An Anthology. Oxford: Oxford University Press.

De Zanet, Alba, and Roberto Garcia. Forthcoming. The Drag Dictionary: An Illustrated Glossary of Fierce Queen Slang. London: Hardie Grant.

Desmond, Marilynn. 1990. "The Voice of Exile: Feminist Literary History and the Anonymous Anglo-Saxon Elegy.” Critical Inquiry 16 (3): 572-590.

Dinshaw, Carolyn. 1999. Getting Medieval: Sexualities and Communities, Pre- and Postmodern. Durham, NC: Duke University Press.

Dodwell, C. R. 2000. Anglo-Saxon Gestures and the Roman Stage. Cambridge: Cambridge University Press.

Dumitrescu, Irina. 2018. "Violence: Ælfric Bata's Colloquies.” In The Experience of Education in Anglo-Saxon Literature, 60-89. Cambridge: Cambridge University Press.

Edlich-Muth, Miriam. 2014. "Prosopopoeia: Sharpening the Anglo-Saxon Toolkit." English Studies 95 (2): 95-108.

Farrier, Stephen. 2016. “That Lip-Syncing Feeling: Drag Performance as Digging the Past.” In Queer Dramaturgies: International Perspectives on Where Performance Leads Queer, edited by Alyson Campbell and Stephen Farrier, 192-209. Houndmills: Palgrave Macmillan.

Farrier, Stephen. 2017. "International Influences and Drag: Just a Case of Tucking or Binding?" Theatre, Dance and Performance Training 8 (2): 171-187.

Fell, Christine. 1984. Women in Anglo-Saxon England. London: British Museum.

Foot, Sarah. 2000. The Disappearance of Nuns from Anglo-Saxon England. Vol. 1 of Veiled Women, 2 vols. Aldershot: Ashgate. 
Frye, Marilyn. 1983. "Lesbian Feminism and the Gay Rights Movement: Another View of Male Supremacy, Another Separatism.” In The Politics of Reality: Essays in Feminist Theory, 128-151. Trumansburg: Crossing Press.

Fulk, R. D., Robert E. Bjork, and John D. Niles, eds. 2008. Klaeber's Beowulf, 4th ed. Toronto: University of Toronto Press.

Gameson, Richard. 1996. "The Origin of the Exeter Book of Old English Poetry." Anglo-Saxon England 25: 135-185.

Goldsmith, Margaret E. 1975. “The Enigma of The Husband's Message.” In Anglo-Saxon Poetry: Essays in Appreciation for John C. McGalliard, edited by Lewis E. Nicholson and Dolores Warwick Frese, 242-263. Notre Dame: University of Notre Dame Press.

Greco, Luca. 2012. "Un Soi pluriel: La présentation de soi dans les ateliers drag king." In La Face cachée du genre: Langage et pouvoir des normes, edited by Natacha Chetcuti and Luca Greco, 63-83. Paris: Presses Sorbonne Nouvelle.

Hall, Alaric. 2002. "The Images and Structure of The Wife's Lament." Leeds Studies in English 33: $1-29$.

Harvey, Elizabeth D. 1992. Ventriloquized Voices: Feminist Theory and English Renaissance Texts. London: Routledge.

Hill, Joyce. 2005. "Leofric of Exeter and the Practical Politics of Book Collecting." In Imagining the Book, edited by Stephen Kelly and John J. Thompson, 77-98. Turnhout: Brepols.

Horner, Shari. 2001. The Discourse of Enclosure: Representing Women in Old English Literature. Albany: State University of New York Press.

Ingham, Patricia Clare. 2003. "From Kinship to Kingship: Mourning, Gender, and Anglo-Saxon Community." In Grief and Gender: 700-1700, edited by Jennifer C. Vaught with Lynne Dickson Bruckner, 17-31. London: Palgrave Macmillan.

Kaske, R. E. 1967. "A Poem of the Cross in the Exeter Book: Riddle 60 and The Husband's Message." Traditio 23: 41-71.

Klein, Stacy S. 2006. "Gender and the Nature of Exile in Old English Elegies." In A Place to Believe In: Locating Medieval Landscapes, edited by Clare A. Lees and Gillian R. Overing, 113-131. University Park: The Pennsylvania State University Press.

Klinck, Anne L. 1987. "Animal Imagery in Wulf and Eadwacer and the Possibilities of Interpretation." Papers on Language and Literature 23 (1): 3-13.

Klinck, Anne L. ed. 1992. The Old English Elegies: A Critical Edition and Genre Study. Montreal: McGill-Queens University Press.

Klinck, Anne L. 2012. “Woman's Song in Medieval Western Europe.” In Medieval Oral Literature, edited by Karl Reichl, 521-554. Berlin: De Gruyter.

Langefeld, Brigitte ed. 2003. The Old English Version of the Enlarged Rule of Chrodegang. Frankfurt: Peter Lang.

Lees, Clare A. and Gillian R. Overing. 2011. "Women and the Origins of English Literature." In The History of British Women's Writing, 700-1500, edited by Liz Herbert McAvoy and Diane Watt, 31-40. Houndmills: Palgrave Macmillan.

Lehmann, Ruth P. M. 1969. "The Metrics and Structure of Wulf and Eadwacer." Philological Quarterly 48: 151-165.

Leslie, R. F. ed. 1961. Three Old English Elegies: The Wife's Lament, The Husband's Message, The Ruin. Manchester: Manchester University Press.

Levin, Sam. 2018. "Who Can Be A Drag Queen? Rupaul's Trans Comments Fuel Calls for Inclusion.” The Guardian, March 8. https://www.theguardian.com/tv-and-radio/2018/mar/08/ rupaul-drag-race-transgender-performers-diversity .

Liuzza, R. M. ed. and trans. 2014. Old English Poetry: An Anthology. Peterborough: Broadview Press.

Lucas, Angela M. 1969. “The Narrator of The Wife's Lament Reconsidered." Neuphilologische Mitteilungen 70 (2): 282-297.

McKinnon, Scott. 2018. "RuPaul's Drag Race is Still Figuring Out How to Handle Gender and Race.” The Conversation, June 27. https://theconversation.com/rupauls-drag-race-is-stillfiguring-out-how-to-handle-gender-and-race-96711 . 
Mitchell, Bruce. 1972. “The Narrator of The Wife's Lament: Some Syntactical Problems Reconsidered." Neuphilologische Mitteilungen 73 (1/3): 222-234

Muir, Bernard J. ed. 2000. The Exeter Anthology of Old English Poetry: An Edition of Exeter Dean and Chapter MS 3501, 2 vols. 2nd ed. Exeter: Exeter University Press.

Muir, Bernard J. 2006. "Issues for Editors of Anglo-Saxon Poetry in Manuscript Form." In Inside Old English: Essays in Honour of Bruce Mitchell, edited by John Walmsley, 181-202. Oxford: Blackwell.

Namaste, Viviane K. 2000. Invisible Lives: The Erasure of Transsexual and Transgendered People. Chicago: University of Chicago Press.

Newton, Esther. [1972] 1979. Mother Camp: Female Impersonators in America. Chicago: University of Chicago Press.

Niles, John D. 2003a. "The Problem of the Ending of The Wife's Lament." Speculum 78 (4): 1107-1150.

Niles, John D. 2003b. “The Trick of the Runes in The Husband's Message." Anglo-Saxon England 32: $189-223$.

Norris, Robin. 2013. “Genre Trouble: Reading the Old English Vita of Saint Euphrosyne." In Writing Women Saints in Anglo-Saxon England, edited by Paul E. Szarmach, 121-139. Toronto: University of Toronto Press.

O’Brien O’Keeffe, Katherine. 1990. Visible Song: Transitional Literacy in Old English Verse. Cambridge: Cambridge University Press.

O’Dell, Kaylin. 2018. "Dramatizing Devotion in the Old English Vercelli Homily IV.” The Journal of English and Germanic Philology, 117 (1): 27-55.

Ogden, Dunbar, H. 2002. The Staging of Drama in the Medieval Church. London: Associated University Presses.

Orme, Nicholas. 2009. Exeter Cathedral: The First Thousand Years, 400-1550. Exeter: Impress Books.

Orme, Nicholas. 2013. The Church in Devon: 400-1560. Exeter: Impress Books.

Orton, Peter. 1981. "The Speaker in The Husband's Message." Leeds Studies in English 12: 43-56.

Orton, Peter. 1985. "An Approach to Wulf and Eadwacer." Proceedings of the Royal Irish Academy. Section C: Archaeology, Culture, History, Literature 85C: 223-258.

Plummer, John F. 1981. Introduction to Vox Feminae: Studies in Medieval Woman's Songs, edited by John F. Plummer, 5-17. Kalamazoo: Medieval Institute.

Prosser, Jay. 1998. Second Skins: The Body Narratives of Transsexuality. New York: Columbia University Press.

Renoir, Alain. 1975. "A Reading Context for The Wife's Lament." In Anglo-Saxon Poetry: Essays in Appreciation for John C. McGalliard, edited by Lewis E. Nicholson and Dolores Warwick Frese, 224-241. Notre Dame: University of Notre Dame Press.

Rissanen, Matti. 1969. “The Theme of 'Exile' in The Wife's Lament." Neuphilologische Mitteilungen 70 (1): 90-104.

Robinson, Fred C. 1980. "Old English Literature in its Most Immediate Context." In Old English Literature in Context: Ten Essays, edited by John D. Niles, 11-29. Cambridge: D. S. Brewer.

Robinson, Fred C. 1990. “Old English Poetry: The Question of Authorship.” ANQ: A Quarterly Journal of Short Articles, Notes and Reviews 3 (2): 59-64.

Rupp, Leila J. and Verta Taylor. 2003. Drag Queens at the 801 Cabaret. Chicago: University of Chicago Press.

Schacht, Steven P. 2002. "Four Renditions of Doing Female Drag: Feminine Appearing Conceptual Variations of a Masculine Theme." Gendered Sexualities 6: 157-180.

Scheck, Helene. 2008. "Seductive Voices: Rethinking Female Subjectivities in The Wife's Lament and Wulf and Eadwacer." Literature Compass 5 (2): 220-227.

Schibanoff, Susan. 1982. "Medieval Fraudenlieder: Anonymous Was a Man?" Tulsa Studies in Women's Literature 1: 189-200.

Senelick, Laurence. 2000. The Changing Room: Sex, Drag and Theatre. London: Routledge. 
Sponsler, Clare. 1997. “Outlaw Masculinities: Drag, Blackface, and Late Medieval Laboring-Class Festivities." In Becoming Male in the Middle Ages, edited by Jeffrey Jerome Cohen and Bonnie Wheeler, 321-347. New York: Garland.

Stevens, Martin. 1968. “The Narrator of The Wife's Lament." Neuphilologische Mitteilungen 69 (1): 72-90.

Stevenson, Jane. 2005. “Anglo-Latin Women Poets." Vol. 2 of Latin Learning and English Lore: Studies in Anglo-Saxon Literature for Michael Lapidge, edited by Katherine O'Brien O'Keeffe and Andy Orchard, 86-107. Toronto: University of Toronto Press.

Stokoe, Kayte. 2019. Reframing Drag: Beyond Subversion and the Status Quo. London: Routledge.

Straus, Barrie Ruth. 1981. "Women's Words as Weapons: Speech as Action in The Wife's Lament." Texas Studies in Literature and Language 23 (2): 268-285.

Strings, Sabrina and Long T. Bui. 2014. "'She is Not Acting, She is': The Conflict Between Gender and Racial Realness on RuPaul's Drag Race." Feminist Media Studies 14 (5): 822-836.

The Dictionary of Old English. A to I Online, edited by Angus Cameron, Ashley Crandell Amos, Antonette diPaolo Healey et al. Toronto: Dictionary of Old English Project.https://tapor.library. utoronto.ca/doe/ .

Treharne, Elaine M. 2003. "Producing a Library in Late Anglo-Saxon England: Exeter, 1050-1072." Review of English Studies 54 (214): 155-172.

Treharne, Elaine. 2007. "Bishops and Their Texts in the Later Eleventh Century: Worcester and Exeter." In Essays in Manuscript Geography: Vernacular Manuscripts of the English West Midlands from the Conquest to the Sixteenth Century, edited by Wendy Scace, 13-28. Brepols: Turnhout.

Treharne, Elaine. 2009. “The Bishop’s Book: Leofric's Homiliary and Eleventh-Century Exeter.” In Early Medieval Studies in Memory of Patrick Wormald, edited by Stephen Baxter, Catherine Karkov, Janet L. Nelson, and David Pelteret, 521-537. Farnham: Ashgate.

Tyler, Elizabeth M. 2016. "German Imperial Bishops and Anglo-Saxon Literary Culture on the Eve of the Conquest: The Cambridge Songs and Leofric's Exeter Book." In Latinity and Identity in Anglo-Saxon Literature, edited by Rebecca Stephenson and Emily V. Thornbury, 177-201. Toronto: University of Toronto Press.

Vuille, Juliette. Forthcoming. Holy Harlots in Medieval English Religious Literature: Authority, Exemplarity, and Femininity. Cambridge: D. S. Brewer.

Watt, Diane, and Clare A. Lees. 2011. "Age and Desire in the Old English Life of St Mary of Egypt: A Queerer Time and Place?" In Middle-Aged Women in the Middle Ages, edited by Sue Niebrzydowski, 53-67. Cambridge: D. S. Brewer.

Weiskott, Eric. 2019. "The Exeter Book and the Idea of a Poem.” English Studies 100 (6): 591-603.

Winterbottom, M. ed. and trans. 2007. William of Malmesbury: Gesta Pontificum Anglorum, 2 vols. Oxford: Clarendon.

Woods, Marjorie Curry. 2019. Weeping for Dido: The Classics in the Medieval Classroom. Princeton: Princeton University Press. 